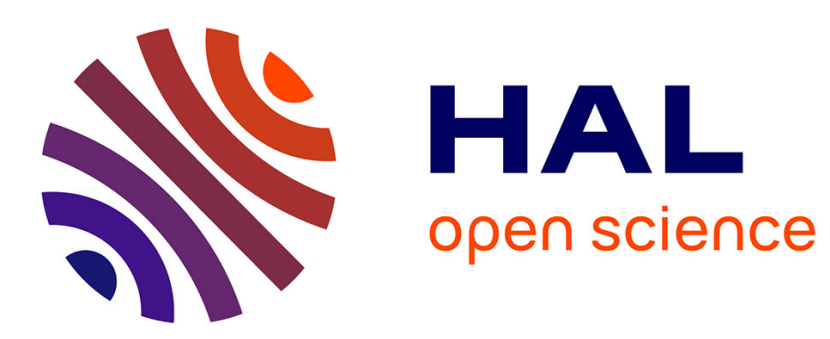

\title{
Decline of genetic diversity of sessile oak at the retracting (xeric) limits
}

\author{
Attila Borovics, Csaba Mátyás
}

\section{To cite this version:}

Attila Borovics, Csaba Mátyás. Decline of genetic diversity of sessile oak at the retracting (xeric) limits. Annals of Forest Science, 2013, 70 (8), pp.835-844. 10.1007/s13595-013-0324-6 . hal-01201523

\section{HAL Id: hal-01201523 \\ https://hal.science/hal-01201523}

Submitted on 17 Sep 2015

HAL is a multi-disciplinary open access archive for the deposit and dissemination of scientific research documents, whether they are published or not. The documents may come from teaching and research institutions in France or abroad, or from public or private research centers.
L'archive ouverte pluridisciplinaire HAL, est destinée au dépôt et à la diffusion de documents scientifiques de niveau recherche, publiés ou non, émanant des établissements d'enseignement et de recherche français ou étrangers, des laboratoires publics ou privés. 


\title{
Decline of genetic diversity of sessile oak at the retracting (xeric) limits
}

\author{
Attila Borovics • Csaba Mátyás
}

Received: 15 January 2013 / Accepted: 18 August 2013 / Published online: 25 September 2013

(C) INRA and Springer-Verlag France 2013

\begin{abstract}
- Context Genetic diversity of sessile oak (Quercus petraea) populations in Hungary was assessed close to the retracting, low-elevation, low-latitude (xeric) distribution limits.

- Objective We aimed at tracing an assumed effect of climatic factors on genetic diversity, particularly at the southern, low elevation limits of distribution.

- Methods Genetic diversity at isozyme-coding loci was analysed in populations, and related to the climate of the sites where the populations grow. A locus-wise analysis proved to be essential to follow responses.

- Results A climate-related cline was found at seven isoenzyme-coding gene loci. Declining allelic numbers and heterozygosity indicated lower diversity at warmer and drier sites. The majority of loci were responsive to precipitation factors, others to temperature. Genetic clustering was neither related to geographic distance nor to random or historic effects. - Conclusions The results suggest that climatic stress may elicit a genetic diversity loss in populations, which may reduce their plasticity and adaptive potential. The selective pressure
\end{abstract}

Handling Editor: Bruno Fady

Contribution of the co-authors A.B.. has designed and realised the field work, has run the data analysis, while C.M. was responsible for the concept, coordination and elaboration of the paper.

Electronic supplementary material The online version of this article (doi:10.1007/s13595-013-0324-6) contains supplementary material, which is available to authorized users.

\footnotetext{
A. Borovics

Department of Forest Tree Breeding, Hungarian Forest Research Institute, H 9600 Sárvár, Várkerület 30/a, Hungary

e-mail: borovics@ertisarvar.hu

C. Mátyás $(\square)$

NEESPI Focus Research Center for Nonboreal Eastern Europe, University of West Hungary, Institute of Environmental and Earth Sciences, 9401 Sopron, POB 132, Hungary

e-mail: cm@emk.nyme.hu
}

may override historic effects and gene flow. With respect to expected climate change, the correlation of diversity with some climatic factors gains specific importance. If supported by further investigations, the results might be utilised for reconsidering conservation strategies and rules for use of forest reproductive material.

Keywords Quercus petraea · Climate change · Isozyme loci · Drought stress · Directional selection · Trailing edge

\section{Introduction}

\subsection{Climatic selection at the retracting, xeric limits}

Declining precipitation, warming, and increasing frequency of droughts are forecasted for continental South-Eastern Europe (Gálos et al. 2012). A specificity of this region is that most dominant tree species reach here their low altitude, low elevation, xeric limit of their distribution (Mátyás et al. 2009), and are consequently strongly exposed to selective effects of climate and of antagonists (diseases and pests).

Selection pressure may be higher on low elevation, relatively flat terrain as compared to mountain conditions, because of faster progress of climatic changes (Jump et al. 2006). Detecting its effects is however more difficult, due to intensive human impact on low-elevation forest cover such as land use change, or replacement of adapted populations with man-made forests. These facts may have contributed to the scarcity of analyses of climate selection of low-elevation forests at the retracting, xeric limits - even though they are highly threatened by potential climate change (Mátyás 2010; Mátyás et al. 2009).

In an earlier study, the role of climatic factors determining the probability of presence of sessile oak in Hungary was modelled. Decision tree models identified early summer precipitation and late summer temperature as the climatic factors 
with the highest potential to discriminate between presence and absence of sessile oak. Aridity indices did not appear among decisive climate factors (Czúcz et al. 2011).

While these results confirmed the outcomes of a growth study of Lebourgeois et al. (2004) in Western France, it has to be remembered that close to the xeric limits, climatic selection acts first of all through extreme events, such as local droughts. Drought events, particularly if repeatedly appearing in subsequent years, are expected to be the decisive selective factors in this region (Rasztovits et al. 2012). Recurrent extreme droughts over subsequent years have happened in the past in every decade, and a worsening of this situation is anticipated for the second half of the present century (Gálos et al. 2012). The oak decline once interpreted as "epidemic" at the time when affecting large parts of Eastern and Central Europe in the 70s and 80s was a consequence of prolonged drought events which led to a significant decimation of populations, and presumably to strong selection (Führer 1992; Führer and Járó 1992). Climatic averages used for detecting selective effects have to be considered therefore rather as proxies for local extremes.

\subsection{Is climatically triggered mortality genetically selective?}

Climatic selection affects primarily quantitative, phenotypic traits such as growth phenology, and may lead to directional selection (for review see Kingsolver et al. 2011). There are however few molecular genetic studies on forest trees which have clearly identified traces of climatic selection. For example, Kelly et al. (2003) found correlations between temperature conditions and seedling AFLP polymorphism in birch. A study applying the same technique in beech, also confirmed the existence of temperature effects on selection in the seedling recruitment phase (Jump et al. 2006). The comparatively faint proofs of climate selection detected by molecular genetic markers seem to be connected with the nature of genetic control of quantitative traits. Due to multigenic inheritance, allele covariances may overwrite the effect of selection on individual loci. Accordingly, the progress of selection is proposed to be slow; its effect may appear after numerous generations only (Alberto et al. 2010; Le Corre and Kremer 2012). On the other hand, widespread symptoms of vitality decline and mortality at the exposed, retracting (xeric) limits of distribution (Allen et al. 2010; Rasztovits et al. 2012) clearly indicate that climatic factors are undoubtedly the primary causes for these limits. The proof that mortality is not random but a manifestation of directional selection is, however, still missing, although this question is of high importance, especially for the valuation of marginal populations; are they products of random genetic processes or of recurrent directional selection? The critical point is to find the causal link between genetic diversity, fitness, and environmental variables. An option for detecting associations is to investigate populations in different climatic environments with probably different fitness criteria.

\subsection{Tracing the effects of selection at isozyme coding loci}

The tracing of impacts of selection promises clearer results at loci under putative monogenic control, such as Kettlewell's classic experiments on melanism in peppered moth. Isozyme coding loci provide such an opportunity; however, these metabolic loci are routinely considered selectively neutral. Genetic variation detected by isozymes is interpreted as the effect of random events such as drift, isolation, or gene flow (e.g., Merilä and Crnokrak 2001; Steinke et al. 2008). Studies of populations exposed to different climatic/ecological conditions have, however, yielded contradicting evidence. Several studies successfully identified allozymatic diversity patterns along altitude. Altitudinal differentiation of allozyme frequencies has been described in conifers for ponderosa pine (Mitton et al. 1980), Aleppo pine (Kara et al. 1997) and recently for European larch, spruce, and mountain pine by Müller-Starck et al. (2012). Altitudinal variation in isozyme coding loci of broadleaved species was reported, for example, by Belletti and Lanteri (1996) for beech, by Premoli (2003) for Nothofagus pumilio and by Zanetto and Kremer (1995) for sessile oak.

Some correlative studies attempted also the identification of the underlying selective climatic or ecological factor. Stutz and Mitton (1988) detected at isozyme loci of Picea engelmanni traces of natural selection when comparing drought-exposed and wet sites. Bergmann and Gregorius (1993) observed in European silver fir a latitudinal cline of Idh enzyme alleles, attributed to thermostability. Mitton and Duran (2004) found in Pinus edulis a very high correlation between the frequency of one Gly allele and summer precipitation. We believe that allozyme diversity clines along ecological gradients cannot be interpreted solely as random effects of gene flow, drift, or inbreeding, and correlations with climatic factors may provide evidence for effective climatic selection.

\section{Research aims}

A more convincing proof for climatic selection at isozyme coding loci would be the existence of climate-related allozymatic frequency patterns in a relatively flat landscape with a strong climatic gradient where gene flow is uninhibited. Such landscapes are found at the low-elevation, retracting limits of species.

Sessile oak [Quercus petraea (Matt.) Liebl.] was selected as the model species because it is a dominant climatedependent tree species exhibiting a largely contiguous, zonal distribution along the lower edge of the closed forest belt in Hungary, with negligible altitudinal differentiation, and therefore well-suited for testing the research hypothesis. The species is abundant in the hills of Transdanubia and Northern Hungary, and reaches its distribution range limits at the edges of the extensive plains (Fig. 1). 
Fig. 1 Distribution of sessile oak in Hungary, and location of the 15 sampled stands

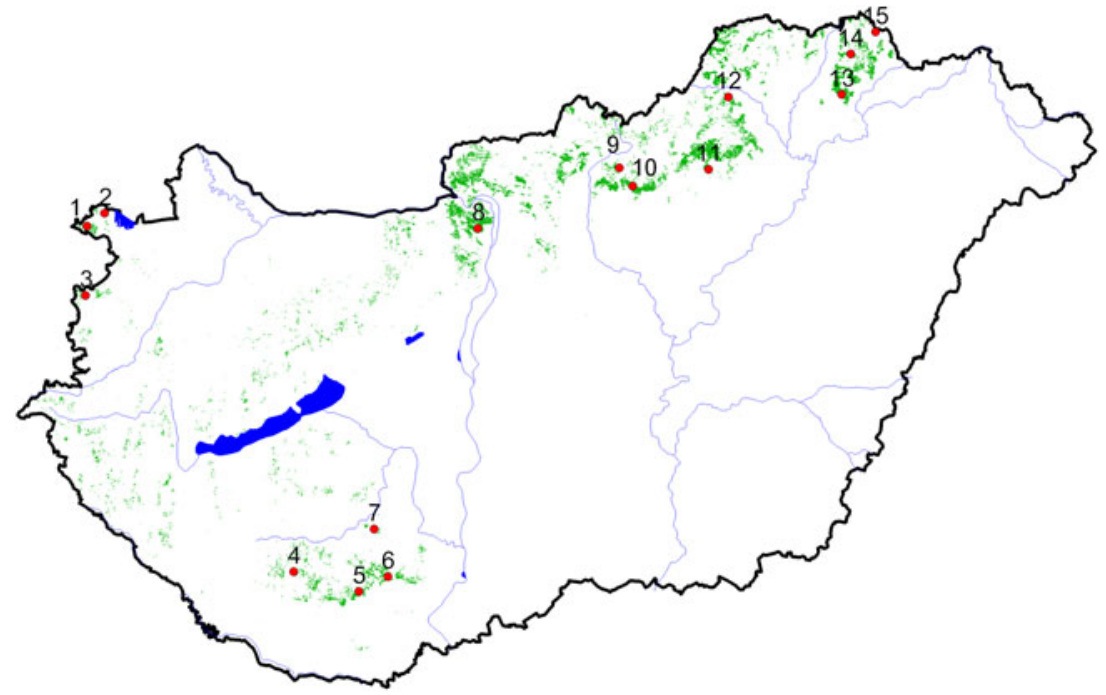

The research hypothesis was that at the retracting or xeric distribution limit (Mátyás et al. 2009), the mesoclimatic status of populations, i.e., precipitation and temperature conditions determine a directional selection, and consequently an allelic frequency cline. Other unpublished studies indicated that silvicultural tending enhances natural selection by preferring genotypes of higher growth potential. Forest stands were considered to be displaying post-selection allele frequencies. An association between allele frequency and climatic factors was expected to reflect the result of the human-supported spontaneous fitness selection.

Genetic differentiation was investigated on individual isozyme-coding gene loci by tracing correlations between climate factors and allozymatic diversity.

The investigation addressed the following questions:

1. Does genetic differentiation among stands indicate an effect of climatic factors at isozyme-coding loci?

2. What is the relation between geographic and genetic distance of populations?

3. Are marginal populations genetically depleted, or accumulating novel adaptations?

\section{Materials and methods}

\subsection{Selecting sites for analysis}

We have retrospectively analysed data of a genetic inventory of polymorphic enzyme loci which was carried out in 2006 in sessile oak stands across its distributional range in Hungary. Fifteen populations have been analysed, representing a broad variation of climatic conditions. The location of sites is shown in Fig. 1, while Fig. 2 illustrates their position in the climatic space. The climatic conditions of the populations varied between exposed, close to the limits (pop. 2, 11, 12), moderately stressed (pop. 4, 7, 8, 9, 13, 15) and relative optimum (pop. 1, 3, 5, 6, 10, 14), offering a gradient suitable for the intended analysis (detailed geographic, climatic, and stand data are listed in the online resource 1).

To filter out the effects of soil conditions grossly exceeded the possibilities of the study. Hence, sites with extreme edaphic or hydrologic conditions were omitted. All stands were classified as water-losing sites of medium or partly above medium yield class, with soils of proper water-holding capacity (clay, loam). An exception is location 2 with shallow soil and below average site class. However, the extreme climatic data of the site fully explain its outlier status (Fig. 2). Hence, the sites were considered climate dependent (zonal), and the analysis did not include soil or hydrology variables.

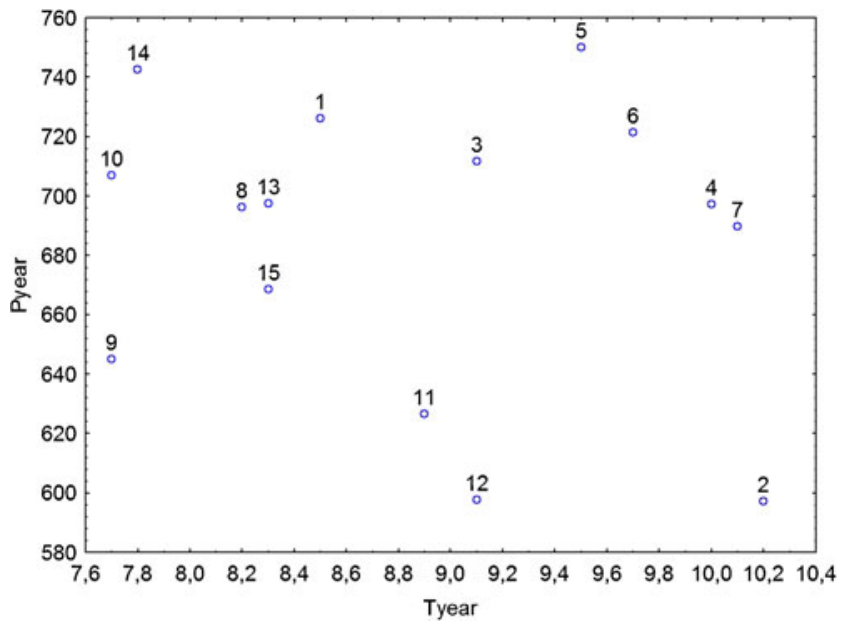

Fig. 2 Position of the sampled stands in the climatic space ("niche") of mean annual temperature (Tyear) and annual precipitation (Pyear). Numbers represent the 15 sampled oak stands. Compare the position of the geographically close point pairs 1, 2 as well as 10, 11 in Figs. 1 and 3 
In the investigated region of submontane hills, altitudinal variation is weak; the selected stands are situated mostly between 350 and $450 \mathrm{~m}$ a.s.l. The distribution of sessile oak is contiguous; gene flow between stands is uninhibited. The age of the populations varied between 56 and 104 years in the year of the sampling. Stand size was between 6 and 25 ha, i.e., the number of trees were generally above 3,000 , up to 20,000 per population (online resource 1). Keeping other selective effects such as human interference at a quasi-uniform, comparable level is of elementary importance for the identification of climate effects. All investigated forest stands have been in state property for half a century. It may be assumed that all populations underwent a similar type and intensity of modest silvicultural selection (thinnings).

\subsection{Climate data of sites}

Monthly mean precipitation and temperature data of the Hungarian Meteorological Service (OMSz) served as basis for the analysis. The initial dataset included data of 31 temperature stations for the 1951-2000 period and precipitation data from 594 stations for the 1974-2005 period. Monthly temperature and precipitation surface maps were compiled using kriging interpolation. The reliability and quality of the technique was assessed by cross-validation. With the help of the surface maps, local climate data were estimated for every population.

In total, 18 temperature, 15 precipitation variables, and three aridity indices (combinations between temperature and precipitation data) have been calculated from the average monthly values (details in: Mátyás and Nagy 2005). In addition to monthly precipitation and temperature means, two direct climate parameters were used: annual number of summer days (above $25^{\circ} \mathrm{C}$ maximum) and of hot days (above $30{ }^{\circ} \mathrm{C}$ daily maximum). These extremes were available for the period of 1961-1990. Only the variables listed in Table 1 have shown significant correlations with diverse genetic parameters. All variables were directly or indirectly related to the vegetation period or characterised extremes. For instance, mean precipitation in the accumulation period ( $\mathrm{PaCC}$ ) may influence the survival of subsequent summer droughts.
As mentioned before, climate means were considered only as proxies for extremes. The incorporation of concrete drought data in the study had to be omitted because it would have required reliable historic, local weather data which were unavailable. It is however sensible to assume that for longer periods, mean climate data and weather extremes are correlated.

\subsection{Genetic analysis and variables}

Dormant winter buds were collected from 50 trees per population; the minimum distance between selected trees was kept at one tree height. Enzymes were extracted from meristematic tissues after removing the bud scales. Separation of enzymes was done by horizontal starch gel electrophoresis following standard procedures (Zanetto et al. 1996; Müller-Starck et al. 1996; Müller-Starck 1998). Eleven enzyme systems provided interpretable results (Enzyme Commission number and controlling locus are given in parentheses): aspartate aminotranferase (2.6.1.1; Aat-B), alcohol dehydrogenase (1.1.1.1; Adh-A), glutamate dehydrogenase (1.4.1.3; Gdh-A), esterase (3.1.1.1; Est$A)$, isocitrate dehydrogenase (1.1.1.42; Idh- $B)$, leucine aminopeptidase (3.4.11.1; Lap-A), menadione reductase (1.6.99.2; Mnr-A), 6-phosphogluconate dehydrogenase (1.1.1.44; 6$P g d h-B$ ), phosphoglucose isomerase (5.3.1.9; Pgi-B), phosphoglucomutase $(2.7 .5 .1 ; P g m-A)$, shikimic dehydrogenase (1.1.1.25; $S k d h-A)$. Alleles were labeled and interpreted according to Müller-Starck et al. (1996).

Population genetic parameters were computed with POPGENE Version 1.32 software (Yeh 2000) from individually scored genotype data sets. The following single locus genetic parameters were calculated for every population: number of genotypes, allele frequency, observed number of alleles $\left(N_{a}\right)$, effective number of alleles $\left(N_{e}\right)$, observed heterozygosity $\left(H_{o b s}\right)$, expected heterozygosity $\left(H_{\text {exp }}\right)$, and fixation index $\left(F_{\text {is }}\right)$.

Genetic distances between populations (Nei 1972) were calculated, and a dendrogram was constructed using the unweighted pairgroup method (UPGMA, Sneath and Sokal 1973). Two-dimensional ordination has been determined from the genetic distance matrix using non-metric multidimensional scaling (Guttman 1968; Borg and Lingoes 1987).

Table 1 Climate variables yielding significant correlations with genetic parameters

Tcont - Range of monthly temperature means, continentality (Tmax-Tmin) Pveg — Sum of precipitation of the vegetation period (April-October)

$T>30$ - Number of hot days (above $30^{\circ} \mathrm{C}$ maximum)

Tsum - Mean temperature of summer months (June, July, August)

$P s p r$ - Sum of precipitation of the spring months (March, April, May)

Pyear - Annual mean precipitation

Pmin - Sum of precipitation of the driest month

Paut - Sum of precipitation of the autumn months (September, October, November)

Ppos - Sum of precipitation of frost-free months

Pwin - Sum of precipitation of the winter months (December, January, February)

Pacc - Sum of precipitation of the accumulation period (November-March) 


\section{Results}

4.1 Comparing genetic analysis results and geographic patterns

Among the populations, the observed number of alleles $\left(N_{a}\right)$ varied from 3.7 to 4.8 , averaging 4.3, effective number of alleles $\left(N_{e}\right)$ varied from 1.78 to 2.10 averaging 1.90 , observed heterozygosity $\left(H_{o b s}\right)$ varied from 0.16 to 0.29 , averaging 0.24 , expected heterozygosity $\left(H_{\text {exp }}\right)$ varied from 0.38 to 0.46 , averaging 0.41 , and fixation index $\left(F_{i s}\right)$ varied from 0.33 to 0.58 , averaging 0.42 . The measure of population differentiation, Nei's $F_{s t}$ was 0.0563 . In other words, $5.63 \%$ of the genetic variation could be assigned to differentiation among populations. (Online resource 2 contains detailed genetic statistics for each of the 15 populations.)

The UPGMA dendrogram of genetic distances did not disclose a geography-based clustering of stands (compare position of sites in Figs. 1 and 3). Neither did a twodimensional ordination diagram of pooled data reveal any geographic pattern (not shown). The relationship between genetic and geographic distance was examined also with the Mantel test using PASSaGE software (Rosenberg and Anderson 2011). There was no significant relationship ( $r=$ 0.081 , two-tailed $p=0.404)$. The position of the sampled sites in the climatic space (Fig. 2) explains the discrepancy between the genetically-based clustering and the geographic position.

Comparison of position of populations in Figs. 1, 2, and 3 is instructive, particularly those of population pairs 1 and 2 as well as of 10 and 11 . These pairs are geographically close, but separated by a steep climatic gradient - illustrating the uncertainty of judgment based on geographic distance. There are a number of other reasons that may contribute to obscuring the geographic patterns of diversity (see in discussion chapter).

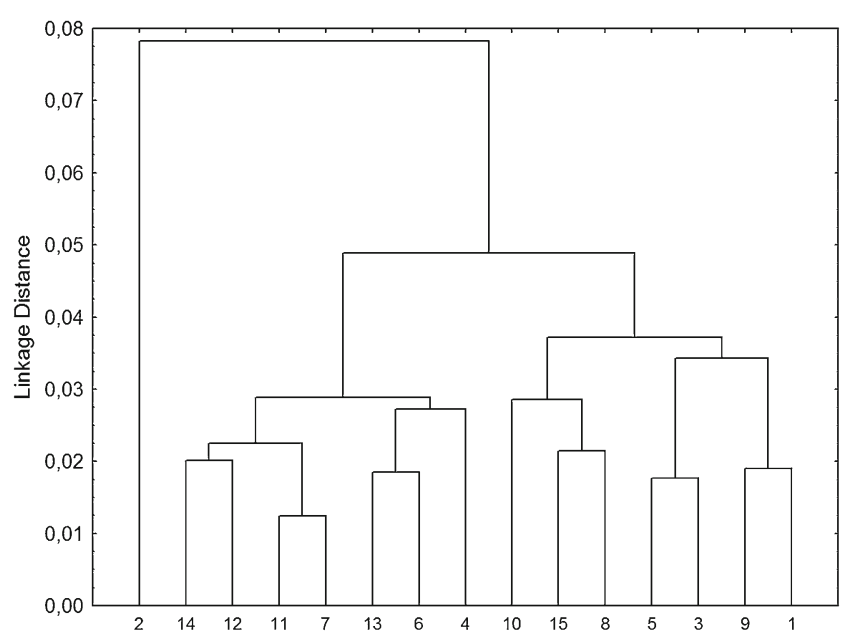

Fig. 3 Tree diagram of genetic distance of 15 sessile oak populations, using the unweighted pair-group average method (numbers represent the 15 sampled oak stands)
4.2 Correlations between climate factors and allele frequencies

Correlations were calculated by locus and by climatic variable. In the following, only enzyme systems, genotypes, and alleles are shown and discussed which repeatedly yielded coefficients below the error probability limit of $p \leq 0.05$ (Tables 2, 3, and 4). Due to the specific character of the data, beside the standard $p \leq 0.05$, error probability of $p \leq 0.01$ was also applied to minimise misinterpretation, analogue to the rigour of the Bonferroni correction. Tables 2, 3, and 4 show that more than half of the correlations significant at $p \leq 0.05$ passed the rigorous level of $p \leq 0.01$. Some of the correlations were significant at an even higher level (e.g., see statistics in Figs. 4 and 5). We decided to show all correlations in the matrix, as cross-correlations exist both between certain climate parameters, and also between genetic parameters. The robustness of correlations is especially obvious at the $S k d h-A$ locus (Fig. 5). In general, less tight correlations were found for the fixation index, a secondary parameter (Table 4).

Distinctive correlations have been found at seven isoenzyme-coding gene loci (Adh-A, Gdh-A, Est-A, Lap-A, 6-Pgdh-B, Pgm-A, Skdh-A). At four other isoenzyme-coding loci, no significant response was detected (Aat-A, Idh-B, Mnr$A$, Pgi-B).

Allele and genotype frequencies and diversity parameters did not correlate with all investigated climatic variables (Table 1). In accordance with the earlier study (Czúcz et al. 2011), no aridity index was among them. Variables of singular months did not yield significant results; means of longer time periods (e.g., summer, vegetation period) or - in one case a more general definition of the monthly average (rainfall in the driest month, Pmin) provided interpretable results. Within-locus allele and genotype frequency data are of course interdependent (e.g. Est-A2 vs. Est-A4 for temperature, or $S k d h-A 2$ vs. $S k d h-A 3$ and $S k d h-A 4$ for precipitation, Table 2). Similar interdependence exists between allelic number, heterozygosity, and fixation statistics.

The results in Tables 2, 3, and 4 show that climate stress (higher mean temperature, lower rainfall) affects genetic diversity negatively. (The opposite signs of correlation coefficients for temperature versus precipitation indicate the same, as increasing values for temperature denote the reverse as the same for precipitation.) The decline of heterozygosity is indicated by diversity parameters. Two loci responded to temperature increase with decline of heterozygosity (Adh-A, Est-A), while others responded similarly to decreasing precipitation (Lap-A, $S k d h-A$, indirectly indicated also for $P g m-A$ by $F_{i s}$ ). Higher aridity of location clearly favoured certain alleles (Lap-A4; Gdh-A4; Pgm-A2; Skdh-A3). Homozygots of the same alleles (Lap-A44, Gdh-A44, Pgm-A22, Skdh-A33) have shown consequently the same response (Table 3 ). With decreasing precipitation, observed and effective allelic numbers 
Table 2 Correlations between climate parameters and allele frequencies
** significant at $p<0.05$, ** significant at $p<0.01$

\begin{tabular}{llllllll}
\hline Allele & Tsum & Pyear & Ppos & Pacc & Pveg & Pmin & Pspr \\
\hline Adh-A3 & -0.22 & +0.49 & +0.18 & $+0.61^{*}$ & +0.26 & $+0.63^{* *}$ & $+0.67^{* *}$ \\
Adh-A5 & $+0.53^{*}$ & $-0.64^{* *}$ & -0.25 & $-0.58^{*}$ & -0.50 & $-0.54^{*}$ & $-0.73^{* *}$ \\
Adh-A6 & +0.22 & -0.45 & -0.10 & -0.47 & -0.30 & $-0.54^{*}$ & $-0.65^{* *}$ \\
Est-A2 & $-0.60^{*}$ & +0.10 & -0.14 & +0.07 & +0.10 & -0.06 & +0.19 \\
Est-A4 & $+0.57^{*}$ & -0.20 & +0.07 & -0.17 & -0.18 & +0.02 & -0.17 \\
Lap-A4 & +0.17 & $-0.62^{*}$ & $-0.58^{*}$ & -0.48 & $-0.55^{*}$ & -0.43 & -0.45 \\
Gdh-A4 & -0.11 & -0.50 & $-0.69^{* *}$ & -0.37 & -0.46 & -0.9 & -0.24 \\
Pgm-A2 & +0.30 & $-0.69^{* *}$ & -0.44 & $-0.64^{* *}$ & $-0.52^{*}$ & $-0.65^{* *}$ & $-0.67^{* *}$ \\
Pgm- $A 4$ & -0.08 & -0.50 & +0.38 & $+0.53^{*}$ & +0.34 & $+0.56^{*}$ & +0.49 \\
Skdh-A2 & +0.19 & +0.51 & $+0.59^{*}$ & -0.43 & +0.42 & $+0.61^{*}$ & +0.37 \\
Skdh-A3 & +0.18 & $-0.82^{* *}$ & $-0.74^{* *}$ & $-0.67^{* *}$ & $-0.69^{* *}$ & $-0.75^{* *}$ & $-0.66^{* *}$ \\
Skdh-A4 & -0.26 & $+0.53^{*}$ & +0.34 & +0.49 & +0.41 & $+0.52^{*}$ & $+0.58^{*}$ \\
\hline
\end{tabular}

$\left(N_{a}, N_{e}\right)$, as well as heterozygosity declined at Lap-A and $S k d h-A$ loci. $N_{e}$ decreased also with increasing continentality at locus Est- $A$ (Table 4). The response of the fixation index $\left(F_{i s}\right)$ to climatic factors is merely the reflection of heterozygosity decline and not an inbreeding effect (Table 4). In the following, the response to climatic factors is described by enzyme systems (see Tables 2, 3, and 4).

$\boldsymbol{A d h}-\boldsymbol{A}$ : was found sensitive to both temperature and precipitation. The locus responded to continentality (Tcont) with decreasing $H_{o b s}$ (Fig. 4), indicated by decline of the frequency of heterozygote genotype 13 . Allelic frequencies were stronger correlated with precipitation.

$\boldsymbol{E} \boldsymbol{s} \boldsymbol{-}-\boldsymbol{A}$ : alleles responded only to temperature differences. Frequency of genotype 24 displayed a tight negative correlation with number of hot days $(T>30)$. Heterozygosity $\left(H_{\exp }\right.$ and $\left.H_{o b s}\right)$ and effective allelic number $\left(N_{e}\right)$ decreased with summer heat $(T>30)$, respectively with continentality (Tcont).

6-Pgdh-B : significant correlation was found only for the heterozygote genotype 34 , which seemed to be tolerant to summer heat $(T>30)$. It is worth mentioning that heterozygote superiority was also reported for this enzyme system for heat tolerance in Pisum (Rabe and Kreeb 1980), and also in Gentiana (Oostermeijer et al. 1995).

The following loci displayed significant correlations with precipitation variables only:

$\boldsymbol{L a p}-\boldsymbol{A}$ : allele 4 stands out with its tolerance to aridity: the frequency of the allele and its homozygot genotype 44 increased with decreasing precipitation variables. Irrespective of the time period, lower rainfall data resulted in lower observed heterozygosity and allelic numbers (see also online resource 3 ).

$\boldsymbol{G d h} \boldsymbol{A}$ : allele 4 and genotype 44 displayed correlations with rainfall variables.

$\boldsymbol{P g} \boldsymbol{m}-\boldsymbol{A}$ : higher aridity significantly increased the frequency of allele 2, of genotypes 22 and 24. The negative correlation with the fixation index $\left(F_{i s}\right)$ for the closely related variables Pacc, Paut, and Pwin indicates that with lower rainfall, heterozygosity at this locus is declining.

Table 3 Correlations between climate parameters and genotype frequencies

\begin{tabular}{|c|c|c|c|c|c|c|c|c|}
\hline Genotype & Tcont & $T>30$ & Pyear & Paut & Ppos & Pacc & Pveg & Pmin \\
\hline Adh-A13 & $-0.72^{* *}$ & +0.05 & +0.39 & $+0.59^{*}$ & +0.50 & $+0 ., 23$ & +0.40 & +0.15 \\
\hline $6 P g d h-B 34$ & +0.09 & $+0.66^{* *}$ & -0.28 & -0.13 & $-0 ., 05$ & +0.01 & -0.42 & -0.08 \\
\hline Est-A24 & -0.11 & $-0.71^{* *}$ & +0.04 & -0.16 & -0.32 & +0.04 & +0.02 & -0.01 \\
\hline Lap-A44 & +0.48 & -0.02 & $-0.76^{* *}$ & $-0.75^{* *}$ & $-0.66^{* *}$ & $-0.66^{* *}$ & $-0.62^{*}$ & $-0.64^{*}$ \\
\hline$G d h-A 44$ & +0.33 & -0.02 & $-0.54^{*}$ & $-0.61^{*}$ & $-0.64^{* *}$ & -0.44 & -0.45 & $-0.56^{*}$ \\
\hline Pgm-A22 & +0.27 & +0.04 & $-0.61^{*}$ & $-0.55^{*}$ & -0.42 & $-0.66^{* *}$ & -0.41 & $-0.66^{* *}$ \\
\hline Pgm-A24 & +0.24 & +0.21 & $-0.68^{* *}$ & -0.47 & -0.38 & -0.41 & $-0.69^{* *}$ & -0.44 \\
\hline Skdh-A22 & -0.18 & -0.06 & +0.50 & $+0.59^{*}$ & $+0.61^{*}$ & +0.48 & +0.37 & $+0.62^{*}$ \\
\hline Skdh-A33 & +0.50 & 0,4 & $-0.79^{* *}$ & $-0.73^{* *}$ & $-0.64^{*}$ & $-0.61^{*}$ & $-0.69^{* *}$ & $-0.66^{* *}$ \\
\hline
\end{tabular}

* significant at $p<0.05,{ }^{* *}$ significant at $p<0.01$ 
Table 4 Correlations between climate parameters and population genetic parameters: observed and effective allelic number, observed and expected heterozygosity, fixation index

\begin{tabular}{|c|c|c|c|c|c|c|c|c|c|c|}
\hline & Tcont & $T>30$ & Pyear & Ppos & Pacc & Pveg & Pmin & Pspr & Paut & Pwin \\
\hline \multicolumn{11}{|l|}{$N_{a}$} \\
\hline Lap- $A$ & -0.33 & +0.18 & $+0.61^{*}$ & +0.45 & $+0.66^{* *}$ & +0.40 & $+0.65^{* *}$ & $+0.62^{*}$ & $+0.53^{*}$ & $+0.66^{* *}$ \\
\hline \multicolumn{11}{|l|}{$N_{e}$} \\
\hline Est-A & $-0.61^{*}$ & +0.03 & +0.24 & +0.38 & +0.08 & +0.29 & -0.02 & +0.01 & +0.38 & +004 \\
\hline$S k d h-A$ & -0.47 & -0.14 & $+0.80^{* *}$ & $+0.76^{* *}$ & $+0.66^{* *}$ & $+0.68^{* *}$ & $+0.73^{* *}$ & $+0.62^{*}$ & $+0.81^{* *}$ & $+0.66^{* *}$ \\
\hline \multicolumn{11}{|l|}{$H_{o b s}$} \\
\hline$A d h-A$ & $-0.73^{* *}$ & -0.00 & +0.13 & +0.30 & +0.23 & +0.01 & +0.07 & -0.08 & +0.40 & +0.17 \\
\hline Est-A & -0.01 & $-0.74^{* *}$ & -0.02 & -0.36 & +0.01 & -0.03 & -0.03 & +0.23 & -0.22 & +0.01 \\
\hline Lap-A & -0.20 & +0.05 & $+0.56^{*}$ & +0.37 & $+0.66^{* *}$ & +0.32 & $+0.73^{* *}$ & $+0.61^{*}$ & +0.49 & $+0.69^{* *}$ \\
\hline \multicolumn{11}{|l|}{$H_{\exp }$} \\
\hline Est-A & $-0.61^{*}$ & -0.05 & +0.28 & +0.38 & +0.14 & +0.30 & +0.06 & +0.09 & +0.39 & +0.11 \\
\hline$S k d h-A$ & -0.46 & -0.22 & $+0.86^{* *}$ & $+0.73^{* *}$ & $+0.68^{* *}$ & $+0.75^{* *}$ & $+0.76^{* *}$ & $0.72^{* *}$ & $+0.80^{* *}$ & $+0.69^{* *}$ \\
\hline \multicolumn{11}{|l|}{$F_{i s}$} \\
\hline$A d h-A$ & $+0.76^{* *}$ & -0.01 & -0.21 & -0.32 & -0.42 & +0.01 & -0.24 & -0.07 & -0.46 & -0.36 \\
\hline Lap- $A$ & +0.24 & -0.09 & $-0.59^{*}$ & -0.50 & $-0.61^{*}$ & -0.40 & $-0.69^{* *}$ & $-0.55^{*}$ & $-0.57^{*}$ & $-0.64^{*}$ \\
\hline Est-A & +0.22 & $+0.71^{* *}$ & +0.13 & +0.50 & +0.07 & +0.13 & +0.09 & -0.17 & +0.37 & +0.07 \\
\hline Pgm-A & +0.43 & -0.07 & -0.41 & -0.39 & $-0.60^{*}$ & -0.15 & $-0.54^{*}$ & -0.35 & $-0.53^{*}$ & $-0.59^{*}$ \\
\hline
\end{tabular}

* significant at $p<0.05,{ }^{* *}$ significant at $p<0.01$

Descriptive statistics by populations and by loci are in the supplementary material

$\boldsymbol{S k} \boldsymbol{d} \boldsymbol{h}-\boldsymbol{A}$ : a system strongly influenced by precipitation conditions. Expected heterozygosity $\left(H_{\text {exp }}\right)$ of the locus responded to almost all precipitation variables (Fig. 5). The most frequent allele 3 and homozygote genotype 33 responded strongly to aridity. The most conspicuous are opposite correlations of alleles 2, 3, 4 with precipitation variables, e.g., with that of the driest month (Pmin, Table 2).

\section{Discussion: climate stress and genetic diversity at the xeric limits}

\subsection{Selective climatic factors}

Selection effects cannot be indubitably attributed to singular climate variables even if correlations are significant. Due to the fact that climatic means have been used as proxies for frequency and severity of extreme events, there is an uncertainty in discriminating locally determinant climate variables; moreover, both temperature and precipitation variables are cross-correlated among themselves (not shown). While most rainfall variables were highly correlated with annual precipitation ( $r$ values between 0.88 and 0.90$)$, it is surprising that summer rainfall did not surface among the variables yielding significant coefficients.
The results imply that climatic stress may lead to significant directional selection. Between population differentiation might even be the result of recent extreme events, in the lifetime of the present generation. This may suggest a much faster progress of selection than usually assumed - at least at certain loci.

Although the role of single climate variables is difficult to ascertain, the results suggest that temperature and precipitation factors exert their effects differentiated by loci. This fact

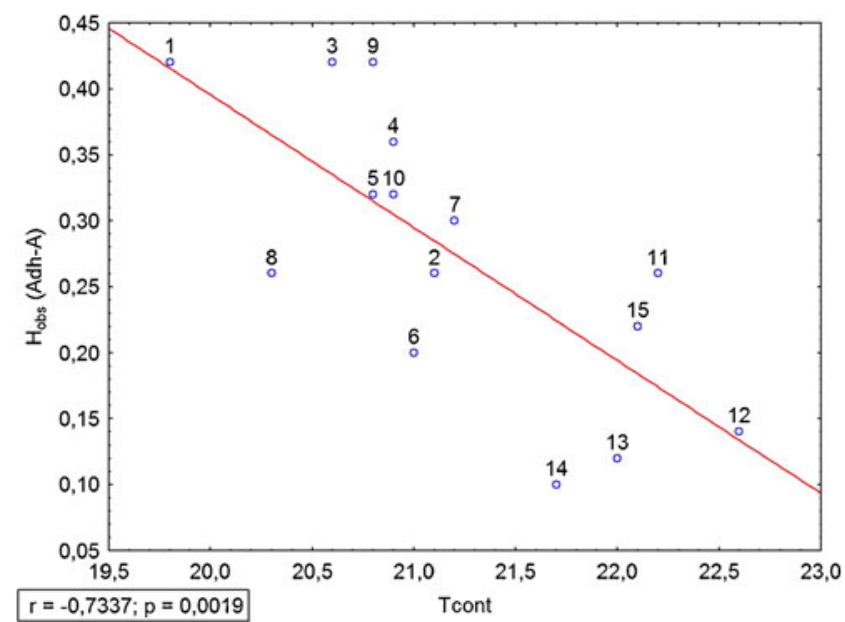

Fig. 4 Decline of observed heterozygosity $\left(H_{o b s}\right)$ with increasing continentality of sites $\left(T_{\text {cont }}\right)$ at the locus $A d h-A$ (numbers represent the 15 sampled oak stands) 


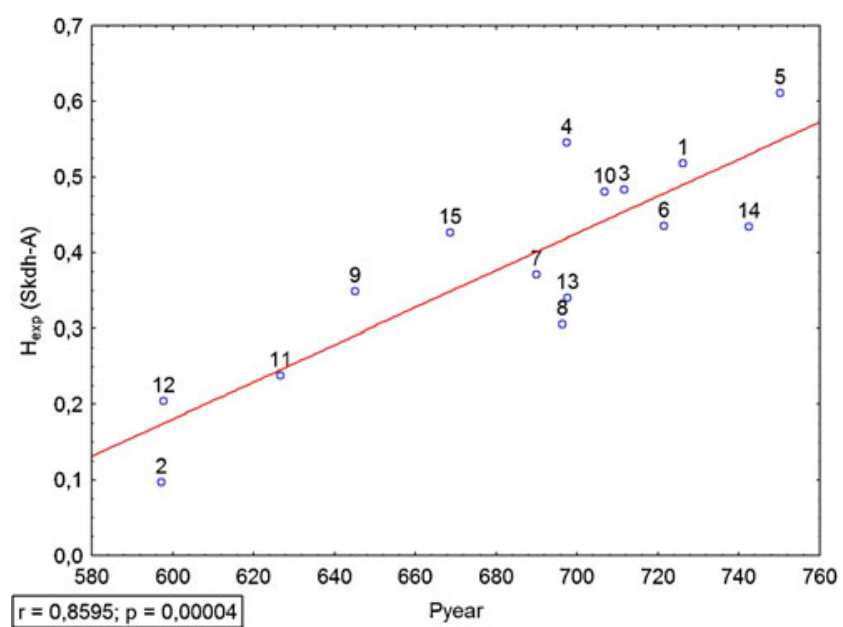

Fig. 5 Correlation of expected heterozygosity $\left(H_{\text {exp }}\right)$ with annual rainfall of sites (Pyear) at the locus $S k d h-A$ (numbers represent the 15 sampled oak stands)

might have contributed to the unexpected lack of correlation with climate (drought) indices, which include both temperature and precipitation factor components. Monthly means also remained insignificant versus more complex variables linked to the vegetation period (e.g., $T>30$, Tsum, Pspr, Pveg, Pmin).

It seems as if temperature's effect is less decisive in oak than that of precipitation. It is improbable that this phenomenon is linked to the higher precision of local rainfall data. The dominance of precipitation factors gets support from the earlier study of the occurrence probability of sessile oak (Czúcz et al. 2011), where precipitation variables appeared more often in the decision tree.

\subsection{Effect of climatic factors on diversity}

Towards the distribution limit, with increasing climatic stress, frequency increase of presumably drought-tolerant alleles and genotypes (Tables 2 and 3) has been observed, leading to lower diversity and a higher level of fixation. The decline of diversity at warmer and drier sites could be directly traced by diversity statistics in case of four loci; two of them (Est-A, Adh-A) responded to temperature increase, the other two $(S k d h-A$, Lap-A) to precipitation decrease (Table 4). Although other studies (e.g., Müller-Starck et al. 2012) have stated the low responsiveness of diversity, none of them have dealt with the extreme conditions close to the xeric distribution limit. Another reason for undetected climatic effects in other studies might be the use of pooled genetic data for discrimination. Pooling data of differently (often oppositely) responding loci may obscure adaptive responses. Pooled statistics provided unsatisfactory results also in this study (not shown).

The assumption that heterozygots may show more tolerance to aridity stress is not supported by our results (genotype $6 P g d h-B 34$ is the exception). The advantage of homo- or heterozygots depends on the concrete adaptive value of the alleles. The frequency change of alleles and genotypes along the climate gradient may indicate their contribution to population fitness. The general decrease of heterozygosity at sensitive loci is considered as the consequence of selection advantage of homozygots at stressed locations (Figs. 4 and 5 and Table 4). This outcome is supported also by observations of Müller-Starck in a translocation experiment. He found an advantage of homozygotes at isozyme loci in "strongly changed environments". Homozygote genotypes seem to be "specialists for extreme conditions" and may have selection advantage (Müller-Starck et al. 2012).

With regard to assumed new adaptations in marginal populations, no traces of novel or rare alleles accumulating at extreme locations have been found in our study.

\subsection{Absence of geographic clusters}

It is not surprising that contrary to Zanetto and Kremer's results (1995), in our study no relation was found between genetic clusters and geographic position of populations. Approaching the lower, xeric limit of distribution, climate stress obviously overrides historic and gene flow effects. Geographic patterns of allozyme frequency, supported by past migration, are more probable on the level of whole distribution ranges (Kremer et al. 1998).

\subsection{Increasing fixation but no cause for inbreeding}

At ecological margins, genetic stochasticity such as low effective population size and isolation by distance may mimic selection effects due to interrupted gene flow and drift. The observed significant increase of $F_{i s}$ at some loci (Adh-A, Lap$A, E s t-A, P g m-A)$ is, however, not an indication of inbreeding. It is the consequence of selection against alleles of lower fitness value leading to a higher level of fixation towards the xeric limits. In our study, neither population size nor isolation by distance justified an increase of fixation. A conservative estimate of the effective number of mating partners in the smallest population (nr. 1) is 400 , and the stand (like all others) is embedded in a contiguous distribution range.

\subsection{Discussion of alternative explanations of observed results}

Alternative explanations for the observed diversity pattern could be the effect of gene flow, linkage with other loci, the introgression of co-existing related white oak species $(Q u$. robur and pubescens), or the different lineage origin of populations. An argument against the effect of gene flow between species is provided by the comparison of diversity of populations 1 and 2 (see Figs. 1 and 5), situated along a steep climatic (but not altitudinal) gradient, within close distance (only $15 \mathrm{~km}$ ). While the relatively heterozygous population 1 is situated in a monospecific environment, with low probability 
of introgression, the other is the most exposed to introgression from related species among all sites, due to its location in an ecologically diverse neighbourhood. As all species were found to be autochthonous at the latter site (Bordács et al. 2002), introgression might have happened over numerous generations. Observed diversity was, however, much lower as in population 1 (see Figs. 4 and 5).

Lineage differentiation of investigated populations offers another alternative explanation for the observed trends. A large-scale $c p D N A$ analysis did not provide any conclusive results which would explain the observed diversity pattern (Bordács et al. 2002). The absence of a geographic component in genetic distance statistics (see chapter 4.1) seems to refute a decisive effect of lineage differences and of gene flow.

Even if the identified effects emerged through linkage, this would not refute the existence of links between diversity and ecologically relevant climate factors. Nevertheless, the putative linkage of investigated loci with QTLs should be further examined. It is worth mentioning that single nucleotide polymorphisms (SNPs) have been identified embedded in genes, bearing signatures of selection, and involved in metabolism, in heat- and disease tolerance of some species, e.g., in Drosophila fly (Sezgin et al. 2004), in killifish (Williams and Oleksiak 2011), and in red abalone (de Wit and Palumbi 2012).

\section{Conclusions}

Expected rapid climatic changes in the next decades will affect first of all presently existing populations. Their adaptive potential will depend largely on available genetic diversity which natural selection can rely on. Up to now, no genetic studies have dealt with the extreme conditions close to the low-elevation, xeric (retracting) limits of distribution.

In the present study, populations under different climatic conditions were compared. At warmer and drier sites, the frequency of presumably drought-tolerant alleles and genotypes increased, leading to the decrease of diversity and a higher level of fixation. The results suggest that severity of climatic stress may trigger a significant diversity loss at adaptive loci under monogenic control. Due to the overriding effect of climate factors, no significant relationship was found between geographic distance and genetic clustering of populations. Robust climatic selection might be the reason for the decline of diversity and higher level of fixation towards the xeric limits, while inbreeding can be excluded in the investigated case. The response of loci was differentiated; the majority of loci were responsive to rainfall conditions, others to temperature.

The loss of genetic diversity in climatically extreme positions is probably taking place at a faster pace than assumed. Although genetic depletion itself is a product of the adaptation process, diversity loss may lead to loss of plasticity and of future adaptive potential.

The analysis of allozymatic diversity may be regarded as a useful tool for investigating the effect of climatic factors. Monogenic isozyme-coding loci seem to be more responsive to climatic effects than quantitative trait loci. It is, however, necessary to further examine the functional role of allele variants (Bergmann and Gregorius 1993; Rothe and Bergmann 1995).

The study of the genetic conditions of populations at the lower, xeric limits of distribution draws attention to the need to consider the importance of the results for forestry and conservation practice. Most remarkable is the lack of regional geographic differentiation, and instead the strong correlation with ecological (climatic) factors which may lead to genetic similarity between distant, but equally exposed populations. If these results are supported by further studies, the adjustment of rules for forest reproductive material use and of the strategy of gene conservation might become necessary.

Acknowledgments The authors acknowledge the helpful support received from Prof. G. Müller-Starck (University München/Freising) and from Dr. M. Konnert (Bavarian ASP Centre). The laboratory and field assistance of K. Cseke and I. Juhász is gratefully acknowledged. The authors thank also the editors and four anonymous reviewers who provided valuable comments to improve the manuscript.

Funding The research was supported by the EC-FP7 projects "EVOLTREE" and "FORGER", as well as by the joint EU-national research project TÁMOP-4.2.2.A-11/1/Konv. "Agrárklíma".

\section{References}

Alberto F, Niort J, Derory J, Lepais O, Vitalis R, Galop D, Kremer A (2010) Population differentiation of sessile oak at the altitudinal front of migration in the French Pyrenees. Mol Ecol 19(13):26262639. doi:10.1111/j.1365-294X.2010.04631.x (accessed Jan 2013)

Allen CD, Macalady AK, Chenchouni H, Bachelet D, McDowell N, Vennetier M, Kitzberger T, Rigling A, Breshears DD, Hogg EH, Gonzalez P, Fensham R, Zhang Z, Castro J, Demidova N, Lim JH, Allard G, Running SW, Semerci A, Cobb N (2010) A global overview of drought and heat-induced tree mortality reveals emerging climate change risks for forests. For Ecol Manage 259:660-684

Belletti P, Lanteri S (1996) Allozyme variation among European beech (Fagus silvatica L.) stands in Piedmont, north-western Italy. Silvae Gen 45:33-37

Bergmann FH, Gregorius HR (1993) Ecogeographical distribution and thermostability of isocitrate dehidrogenase (IDH-A) alloenzymes in European silver fir. Biochem Syst Ecol 21:597-605

Bordács S, Popescu F, Slade D, Csaikl UM, Lesur I, Borovics A, Kézdy P, König AO, Gömöry D, Brewer S, Burg K, Petit RJ (2002) Chloroplast DNA variation of white oaks in northern Balkans and in the Carpathian Basin. Forest Ecol Manage 156:197-209

Borg I, Lingoes J (1987) Multidimensional similarity structure analysis. Springer, New York

Boshier DH, Young AG (2000) Forest conservation genetics: limitations and future directions. In: Young A, Boshier D, Boyle T (eds) Forest 
conservation genetics: principles and practice. CABI Publishing, Wallingford, UK, pp 289-297

Czúcz B, Gálhidy L, Mátyás C (2011) Present and forecasted xeric climatic limits of beech and sessile oak distribution at low altitudes in Central Europe. Ann For Sci 68:99-108

De Wit P, Palumbi SR (2013) Transcriptome-wide polymorphisms of red abalone (Haliotis rufescens) reveal patterns of gene flow and local adaptation. Mol Ecol 22(11):2884-2897. doi:10.1111/mec.12081 (accessed June 2013)

Führer E (1992) Der Zusammenhang zwischen der Dürre und der Erkrankung der Traubeneichenbestände in Ungarn. Forstwiss Cbl 111:129-136

Führer E, Járó Z (1992) Auswirkungen der Klimaänderung auf die Waldbestände Ungarns. Allg Forstztg 9:25-27

Gálos B, Hänsler A, Kindermann G, Rechid D, Sieck K, Jacob D (2012) The role of forests in adapting to climate change - a case study for Europe. Acta Silv Lign Hung 8:87-102

Guttman L (1968) A general nonmetric technique for finding the smallest coordinate space for a configuration of points. Psychometrika 33: 469-506

Jump AS, Hunt JM, Martínez-Izquierdo JA, Peñuelas J (2006) Natural selection and climate change: temperature-linked spatial and temporal trends in gene frequency in Fagus sylvatica. Mol Ecol 15:3469-3480

Kara N, Korol L, Isik K, Schiller G (1997) Genetic diversity in Pinus brutia Ten.: altitudinal variation. Silvae Gen 46:155-161

Kelly CK, Chase MW, de Bruijn A, Fay MF, Woodward FI (2003) Temperature-based population segregation in birch. Ecol Lett 6: 87-89

Kingsolver JG, Diamond SE, Siepielski AM, Carlson SM (2011) Synthetic analyses of phenotypic selection in natural populations: lessons, limitations and future directions. Trends Evol Ecol 26: 1101-1118

Kremer A, Petit R, Ducousso A, Le Corre V (1998) General trends of variation of genetic diversity in Quercus petraea (Matt.) Liebl. In: Proceedings of the Conference of IUFRO Working Party on Genetics of Quercus, State College, Pennsylvania, USA 12-17 October 1997, pp 81-89

Lebourgeois F, Cousseau G, Ducos Y (2004) Climate-tree-growth relationships of a Quercus petraea stand in the forest of Bercé ("futaie des clos", Sarthe, France). Ann For Sci 61:361-372

Le Corre V, Kremer A (2012) The genetic differentiation at quantitative trait loci under local adaptation. Mol Ecol 21(7):1548-1566. doi:10. 1111/j.1365-294X.2012.05479.x (accessed Dec. 2012)

Mátyás C (2010) Forecasts needed for retreating forests (Opinion). Nature 464:1271

Mátyás C, Nagy L (2005) Genetic potential of plastic response to climate change. In: Konnert M (ed) Tagungsberichte, Forum GenetikWald-Forstwirtschaft 2004. Bavarian ASP Centre, Teisendorf, pp 55-69

Mátyás C, Vendramin GG, Fady B (2009) Forests at the limit: evolutionary-genetic consequences of environmental changes at the receding (xeric) edge of distribution. Ann For Sci 66:800-803

Merilä J, Crnokrak P (2001) Comparison of genetic differentiation at marker loci and quantitative traits. J Evol Biol 14:892-903

Mitton JB, Duran KL (2004) Genetic variation in pinon pine, Pinus edulis, associated with summer precipitation. Molec Ecol 13: $1259-1264$
Mitton JB, Sturgeon KB, Davis ML (1980) Genetic differentiation in ponderosa pine along a steep elevational transect. Silvae Gen 29: $100-103$

Müller-Starck G (1998) Isozymes. In: Karp A, Isaac PG, Ingram DS (eds) Molecular tools for screening biodiversity: plants and animals. Chapman and Hall, London, pp 75-81

Müller-Starck G, Zanetto A, Kremer A, Herzog S (1996) Inheritance of isoenzymes in sessile oak (Quercus petraea (Matt.) Liebl.) and offspring from interspecific crosses. Forest Genet 3:1-12

Müller-Starck G, Konnert M, Ziehe M, Klumpp R (2012) Das Translokationsexperiment Koralm: Untersuchungen über den Einfluss der Höhenlage auf die genetischen Strukturen von Lärche, Latsche und Fichte. Forstarch 83:126-135

Nei M (1972) Genetic distance between populations. Am Nat 106:283292

Oostermeijer JGB, van Eijck MW, van Leeuwen NC, den Nijs JCM (1995) Analysis of the relationship between allozyme heterozygosity and fitness in the rare Gentiana pneumonanthe L. J Evol Biol 8: 739-759

Premoli AC (2003) Isozyme polymorphisms provide evidence of clinal variation with elevation in Nothofagus pumilio. J Hered 94:218-226

Rabe R, Kreeb KH (1980) Wirkungen von $\mathrm{SO}_{2}$ auf die Enzymaktivität in Pflanzenblättern. Z Pflanzenphysiol 97:215-26

Rasztovits E, Móricz N, Berki I, Pötzelsberger E, Mátyás C (2012) Evaluating the performance of stochastic distribution models for beech at low-elevation xeric limits. IDÖJÁRÁS 116(3):173-194

Rosenberg MS, Anderson CD (2011) PASSaGE: pattern analysis, spatial statistics, and geographic exegesis. Version 2. Meth Ecol Evol 2: 229-232

Rothe G, Bergmann F (1995) Increased efficiency of Norway spruce heterozygous phosphoenolpyruvate carboxylase phenotype in response to heavy air pollution. Angew Bot 69:27-30

Sezgin E, Duvernell DD, Matzkin LM, Chen YD, Zhu T, Verrelli BC, Eanes WF (2004) Single-locus latitudinal clines and their relationship to temperate adaptation in metabolic genes and derived alleles in Drosophila melanogaster. Genet 168:923-931

Sneath PHA, Sokal RR (1973) Numerical taxonomy. The principles and practice of numerical classification. Freeman and Co., San Francisco, pp 230-234

Steinke LR, Premoli AC, Souto CP, Hedrén M (2008) Adaptive and neutral variation of the resprouter Nothofagus antarctica growing in distinct habitats in north-western Patagonia. Silva Fenn 42:177188

Stutz HP, Mitton JB (1988) Genetic variation in Engelman spruce associated with soil moisture. Arct Alp Res 20:461-465

Yeh F (2000) Population genetics. In: Young A, Boshier D, Boyle T (eds) Forest conservation genetics. Principles and practice. CABI Publishing, Wallingford, UK, pp 21-38

Williams LM, Oleksiak MF (2011) Ecologically and evolutionarily important SNPs identified in natural populations. Mol Biol Evol 28: $1817-1826$

Zanetto A, Kremer A (1995) Geographical structure of gene diversity in Quercus petraea (Matt.) Liebl. I. Monolocus pattern of variation. Hered 75:506-517

Zanetto A, Kremer A, Müller-Starck G, Hattemer HH (1996) Inheritance of izozymes in pedunculate oak (Quercus robur L.). J Hered 87: 364-370 